\title{
1. INTRAPLATE DEFORMATION AND BENGAL FAN SEDIMENTATION: BACKGROUND AND OBJECTIVES 1
}

\author{
Shipboard Scientific Party ${ }^{2}$
}

\section{INTRODUCTION}

Classical plate tectonics assumes that large lithospheric plates behave as rigid units, with deformation confined primarily to their boundaries. Observational evidence suggests, however, that the Indian-Australian Plate is not behaving in this manner, but has been subjected to significant internal compression (Fig. 1). This is evidenced by an unusually large number of intraplate earthquakes, many with thrust focal mechanisms (Sykes, 1970; Banghar, 1972; Fitch et al., 1973; Stein and Okal, 1978; Bergman et al., 1984) and by the inability of plate motion models to successfully reproduce both spreading rates and directions along the boundaries of the Indian plate (Minster and Jordan, 1978; Wiens et al., 1985). However, the most spectacular and direct evidence for internal deformation in the Indian plate are E-W striking large-scale folds and small high-angle faults in the wide region between the Central Indian Ridge and the Ninetyeast Ridge (Eittreim and Ewing, 1972; Weissel et al., 1980).

The observed intraplate deformation affects both the ocean crust and the thick pile of overlying sediments deposited on the distal part of the Bengal Fan. This submarine fan is the largest in the world, extending some $3000 \mathrm{~km}$ from the slope south of the Bengal delta to the Sri Lanka abyssal plain just to the south of the Afanasy Nikitin seamount group (Curray and Moore, 1971; Emmel and Curray, 1984) (Fig. 2). Maximum sediment thickness beneath the upper fan may exceed $16 \mathrm{~km}$ (Curray and Moore, 1971; Curray et al., 1982); the estimated thickness in the region of Leg 116 drilling is between 1.5 and $2 \mathrm{~km}$.

JOIDES Resolution departed Colombo, Sri Lanka, on July 7,1987 . During the 43 days of operations, ten holes were drilled at three sites on small-scale ( 5 to $10 \mathrm{~km}$ wide) rotated fault blocks near $1^{\circ} \mathrm{S}, 81^{\circ} 24^{\prime} \mathrm{E}$ (Fig. 3). These sites were designed to study depositional processes, diagenesis, and the history of movement on two of the fault blocks. All the sites were located at the very distal end of the Bengal submarine fan (Fig. 4), close to the termination of the most recently active main fan channel (Fig. 2). The ship returned to Colombo, Sri Lanka, on August 19, 1987. A total of $3326.2 \mathrm{~m}$ of sediment was drilled, of which $2299.4 \mathrm{~m}$ were cored and $991.4 \mathrm{~m}$ recovered.

The specific objectives of Leg 116 drilling were:

1. To determine the age of onset of the intraplate deformation and the subsequent history of displacement between the fault blocks;

2. To characterize the lithofacies present on the distal Bengal Fan and to determine the depositional processes responsible for them;

3. To investigate the nature of early diagenesis in the submarine fan sediments, especially in relation to the high heat flow;

\footnotetext{
${ }^{1}$ Cochran, J. R., Stow, D.A.V., et al., 1988. Proc. ODP, Init. Repts., 116: College Station, TX (Ocean Drilling Program).

2 Shipboard Scientific Party is as given in the list of Participants preceding the contents.
}

4. To establish the provenance of the terrigeneous sediments and to use compositional variations to document the tectonic uplift history of the Himalayas;

5. To understand the relationship between fault zones, bedding planes, and the flow of water deduced from surface heat flow measurements;

6. To investigate the effects of the regional compressive stress regime and high heat flow on the physical, hydrological, and magnetic properties of the sediment and on the diagenetic process; and

7. To investigate depositional processes and rates through time and the growth of the Bengal Fan, by obtaining a section deposited prior to the onset of intraplate deformation.

\section{GEOLOGICAL AND GEOPHYSICAL BACKGROUND}

The collision between continental India and Eurasia, beginning in the Eocene, had profound effects not only on the tectonics of Asia, but also on the tectonics of, and sedimentation on, the Indian Ocean lithosphere formed in the wake of India during its northward movement. From the late Cretaceous (approximately magnetic anomaly 34 time) to the early Eocene (magnetic anomaly 22), India moved rapidly northward across the Tethys at a rate which Peirce (1978) calculated to be about 15 $\mathrm{cm} / \mathrm{yr}$ relative to the Earth's spin axis. During this time, much of the present Indian Ocean was generated behind India at the Carlsberg and Southeast Indian Ridges by seafloor spreading at half rates of 5.6 to over $12 \mathrm{~cm} / \mathrm{yr}$ (McKenzie and Sclater, 1971; Sclater and Fisher, 1974; Schlich, 1982). A fairly typical abyssal sequence of sediments accumulated in the Central Indian Basin during this period, consisting of carbonates deposited near the ridge crest overlain by clays deposited on the deeper abyssal plain (Davies and Kidd, 1977). These sediments may be several kilometers thick in the north under the present proximal fan, but are probably less than a few hundred meters at $1^{\circ} \mathrm{S}$ (Moore et al., 1974; Curray et al., 1982).

The collision between continental India and Asia is usually assumed to have begun in the Eocene at about the time of Anomaly 22 (approximately $53 \mathrm{Ma}$ ) (e.g., Curray et al., 1982; Patriat and Achache, 1984), based on a decrease in spreading half rates in the central Indian Basin from $8 \mathrm{~cm} / \mathrm{yr}$ to $4 \mathrm{~cm} / \mathrm{yr}$ at this time (Sclater and Fisher, 1974). A regional unconformity observed in the eastern Bay of Bengal, which is taken as marking the initial formation of the Bengal Fan (Curray and Moore, 1971), has been assigned a Paleocene-middle Eocene age based on extrapolation from DSDP Site 217 (Moore et al., 1974). Curray et al. (1982) suggest that this time marks a "soft collision" and that convergence continued between India and Asia for perhaps another $10 \mathrm{Ma}$.

A hard continent-continent collision appears to have occurred in the latest Eocene (about $40 \mathrm{Ma}$ ). The marine evidence includes an additional decrease in spreading rate from 4.0 to 2.5 $\mathrm{cm} / \mathrm{yr}$ and a nearly $45^{\circ}$ change in spreading direction on the Southeast Indian Ridge from N-S to NE-SW (Sclater et al., 1976). This age is also consistent with the end of the emplace- 


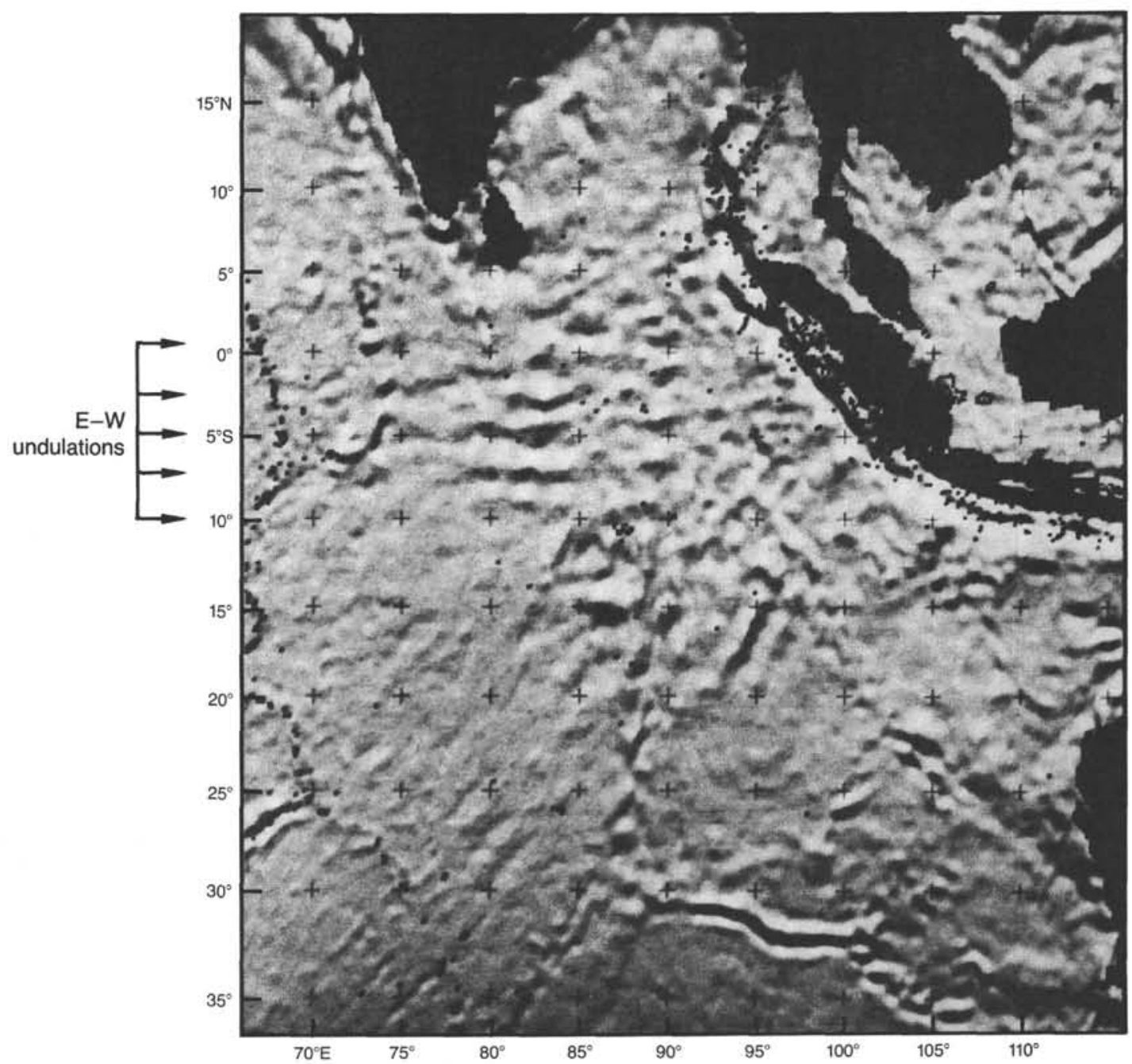

Figure 1. Gray-scale image depicting N-S gradients of SEASAT-derived gravity anomalies in the northern Indian Ocean. Slopes down to the north are light; slopes up to the north are dark. Land areas, $5^{\circ}$ grid cross markers, and dots marking epicenters for shallow earthquakes are black. The E-W-trending gravity anomalies associated with the intraplate deformation are conspicuous in the upper left part of this image (after Weissel, unpublished data).

ment of the Transhimalayan granites (e.g., Bally, Allen et al., 1980; Gansser, 1964, 1966; Honegger et al., 1982; Tapponnier et al., 1981) and the age of obduction of ophiolites along the Yarlung Zangbo suture zone in Tibet (Tapponnier et al., 1981).

A later tectonic event is recorded by the "upper unconformity" of Curray and Moore (1971) that was dated by DSDP Leg 22 drilling to be of late Miocene age (Moore et al., 1974). This unconformity is presumably the same unconformity observed farther south in the central Indian Ocean, where it appears to mark the onset of intraplate deformation (Weissel et al., 1980). Some early studies (Gansser, 1964, 1966; Powell and Conaghan, 1973) suggested that the major uplift of the Himalayas also occurred in the late Miocene, although a number of recent studies (e.g., Copeland et al., 1987) suggest that uplift began earlier. If the lower unconformity of Curray and Moore (1971) represents the onset of Bengal Fan sedimentation, then the implication is that major erosion and thus uplift began as early as the Eocene.

\section{INTRAPLATE DEFORMATION IN THE CENTRAL INDIAN OCEAN}

The resistance to subduction and shortening across the Himalayas, combined with continued spreading on the southeast
Indian Ridge, has presumably placed the central Indian Ocean under a large $\mathrm{N}-\mathrm{S}$ compressive stress regime that is responsible for the observed intraplate deformation in this area. Within the affected region, which extends roughly from the Chagos-Laccadive Ridge eastward to the Ninetyeast Ridge and from $5^{\circ} \mathrm{N}$ to $10^{\circ} \mathrm{S}$ latitude, the oceanic crust and most of the overlying strata are deformed into long-wavelength (100-300 km) undulations (or folds) with peak-to-trough amplitudes of 1-3 km (Weissel et al., 1980; Geller et al., 1983) (Fig. 5). The pattern of E-W trending crustal undulations is clearly revealed in maps of gravity anomalies derived from SEASAT altimeter measurements (Fig. 1) and by surface-ship gravity measurements which show them to be associated with gravity anomaly variations of $30-70 \mathrm{mGal}$ (Weissel et al., 1980). Analysis of the gravity anomalies implies that the Moho is deformed in the same way as the upper surface of the crust (Geller et al., 1983). The deformed area is characterized by an unusually large number of thrust and strike-slip intraplate earthquakes whose foci are located within the mantle (Sykes, 1970; Stein and Okal, 1978; Bergman et al., 1984; Wiens and Stein, 1983, 1984). Directions of maximum compressive stress for a number of these events are approximately perpendicular to the E-W trends of the long-wavelength crustal undulations indicating that deformation is ongoing (Fig. 6). Super- 


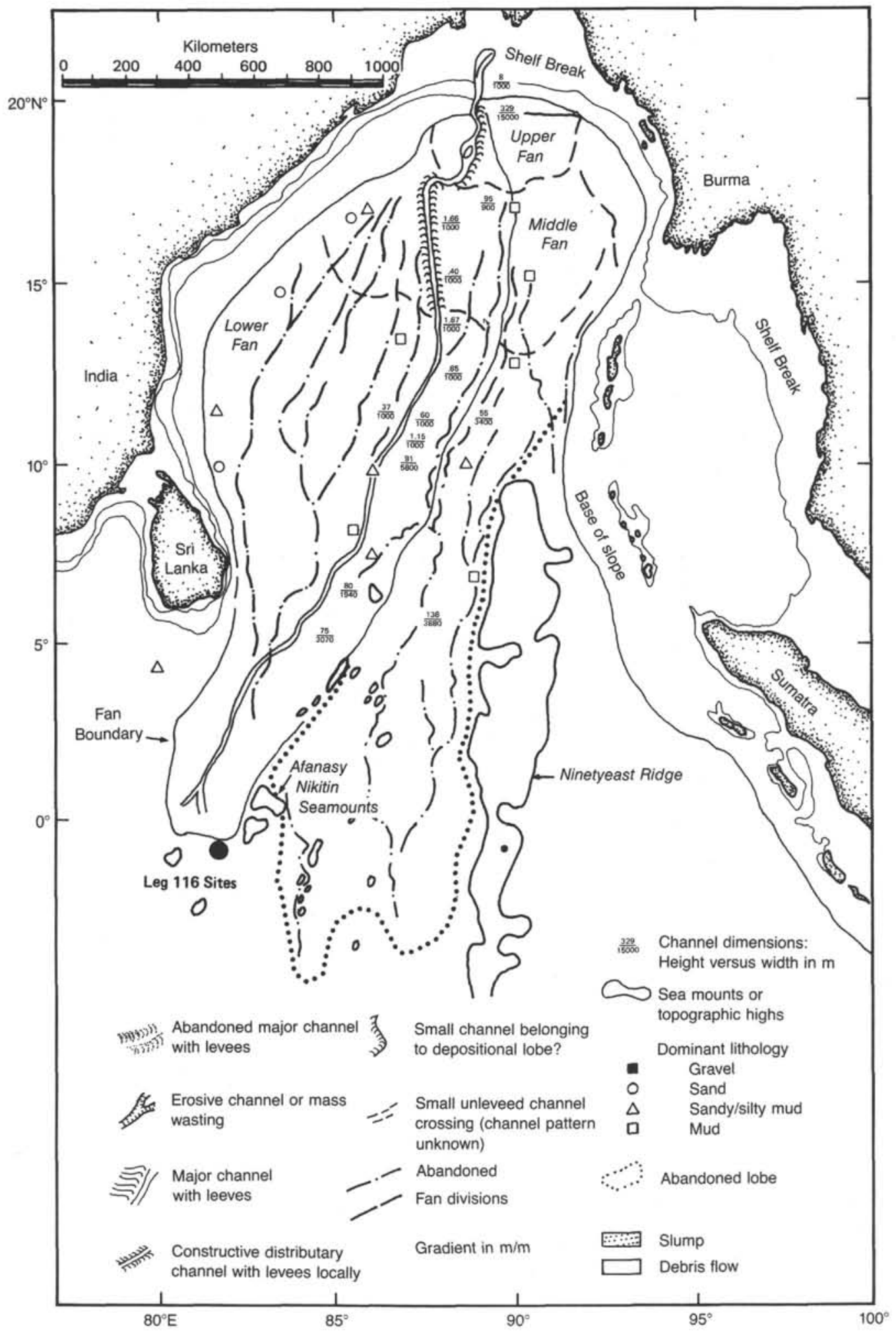

Figure 2. Morphometric map of the Bay of Bengal showing Leg 116 drilling area (after Emmel and Curray, 1984).

imposed on the long-wavelength undulations are fault-bound blocks, 5-20 km wide (Fig. 5). The top of the crust is seen to be offset on seismic reflection records by up to $0.5 \mathrm{~s}$ (>500 m) across the high-angle faults separating blocks (Fig. 5). These observations support the interpretation that the crust deformed der N-S compression and that some amount of lithospheric shortening has occurred.

Heat flow in the deformed region is higher than expected for the age of the underlying crust and shows great scatter in the measurements (Fig. 6). In particular, abnormally high heat-flow 

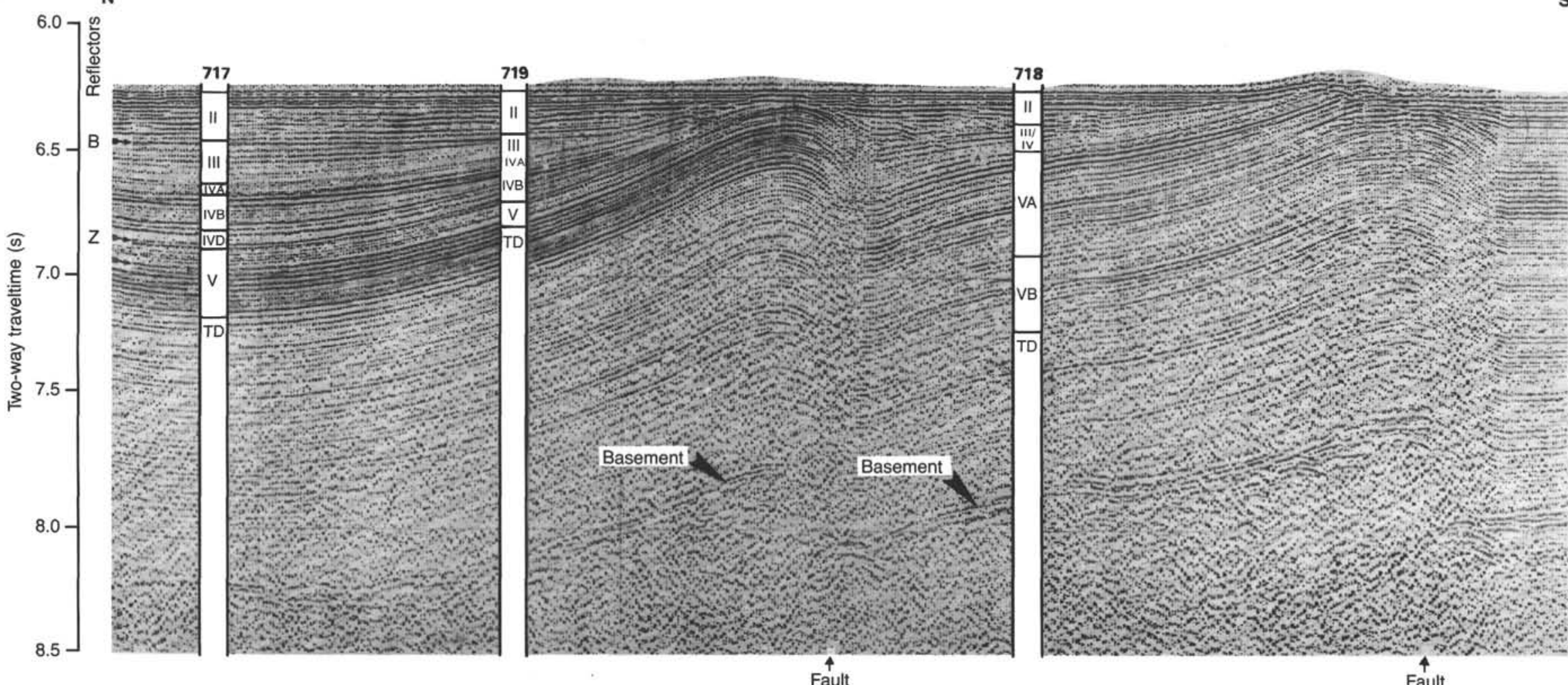

Figure 3. Detail of CONRAD 2706 single-channel seismic line running N-S through Leg 116 sites. Roman numerals at each site denote the lithostratigraphic units drilled (see site chapters and summary). 


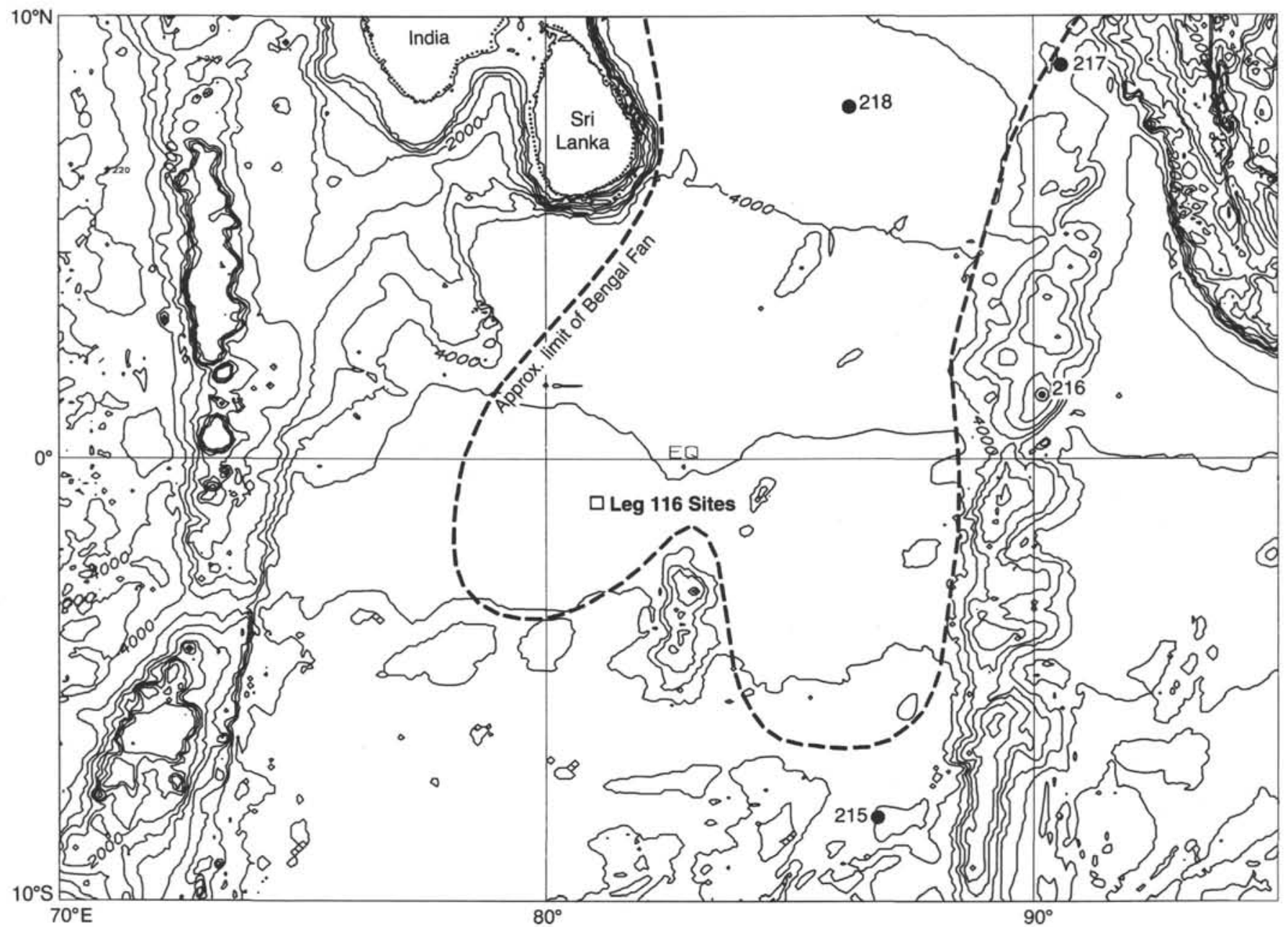

Figure 4. Bathymetric map of Leg 116 area showing the approximate limit of the deep sea Bengal Fan.

values are distributed widely over the central Indian Ocean Basin (Fig. 6) (Anderson et al., 1977; Weissel et al., 1980; Geller et al., 1983). The measured temperature-depth profiles associated with some of the highest values are nonlinear, suggesting an upward flow of water through the sediments (Geller et al., 1983). A detailed heat flow study conducted as part of the precruise site survey for Leg 116 shows that there is great variability in the heat flow on the scale of a few kilometers (Fig. 7). The smallscale variability and the fact that the highest values are not associated with the faults suggest that water is not only flowing along the faults, but may also be ascending along inclined, permeable sediment layers.

The source of the heat and the source of the water may be interrelated. The high heat flow could represent sampling of the upwelling limbs of hydrothermal cells extending into the crust, which have been activated by cracking and faulting during deformation (Geller et al., 1983). In this case, the heat could be partially the result of work required to deform the lithosphere (in the form of viscous dissipation, friction on faults, or plastic deformation). The flow could also be confined to the sedimentary sequence and be the result of dewatering as a result of compressional deformation. It is also conceivable that the distal end of the Bengal Fan represents the discharge zone of artesian flow through permeable sediments in the fan.

\section{FAN SEDIMENTATION}

The Bengal Fan is poorly sampled. Fewer than 100 short cores have been recovered from an area of about $3 \times 10^{6} \mathrm{~km}^{2}$
(Curray and Moore, 1971; Curray et al., 1982); and only one spot-cored DSDP site (Leg 22, Site 218) was drilled in the fan. DSDP Site 218 terminated in middle Miocene sediments at a depth of 772 mbsf (von der Borch, Sclater et al., 1974). The Bengal Fan is assumed to be characteristic of the muddy, deltafed, elongate fan type (Stow, 1985, 1986), with its enormous volume of sediments derived principally from erosion of material from the uplifting Himalayan Mountains and supplied to the delta front via the Ganges-Brahmaputra river systems.

Sediments are funneled very efficiently to the fan via a deltafront trough, the "Swatch-of-No-Ground" (Emmel and Curray, 1984). This trough is presently connected to only one active fan channel, but has been effectively cut off from rapid sediment supply since the most recent rise in sea level, probably about $7000-10,000$ yr ago. Many other channels mark the surface of the fan and extend for various distances along its length. Most of these are thought to have been abandoned by channel switching in the past (Fig. 2).

DSDP Site $218\left(08^{\circ} 00.06^{\prime} \mathrm{N}, 86^{\circ} 16.97^{\prime} \mathrm{E}\right)$ identified four main pulses of sandy turbidites, one in the middle Miocene, two in the late Miocene-Pliocene, and the most recent in the Pleistocene (von der Borch, Sclater, et al., 1974). The intervening sediments are a mixture of turbidite muds and calcareous pelagic units. The short core coverage of the fan has shown that in most cases pelagic muds, $20-90 \mathrm{~cm}$ in thickness, are found overlying thin to thick turbidite sands. The latter are thicker and/or more abundant in and close to channel axes than in interchannel areas (Emmel and Curray, 1984). 


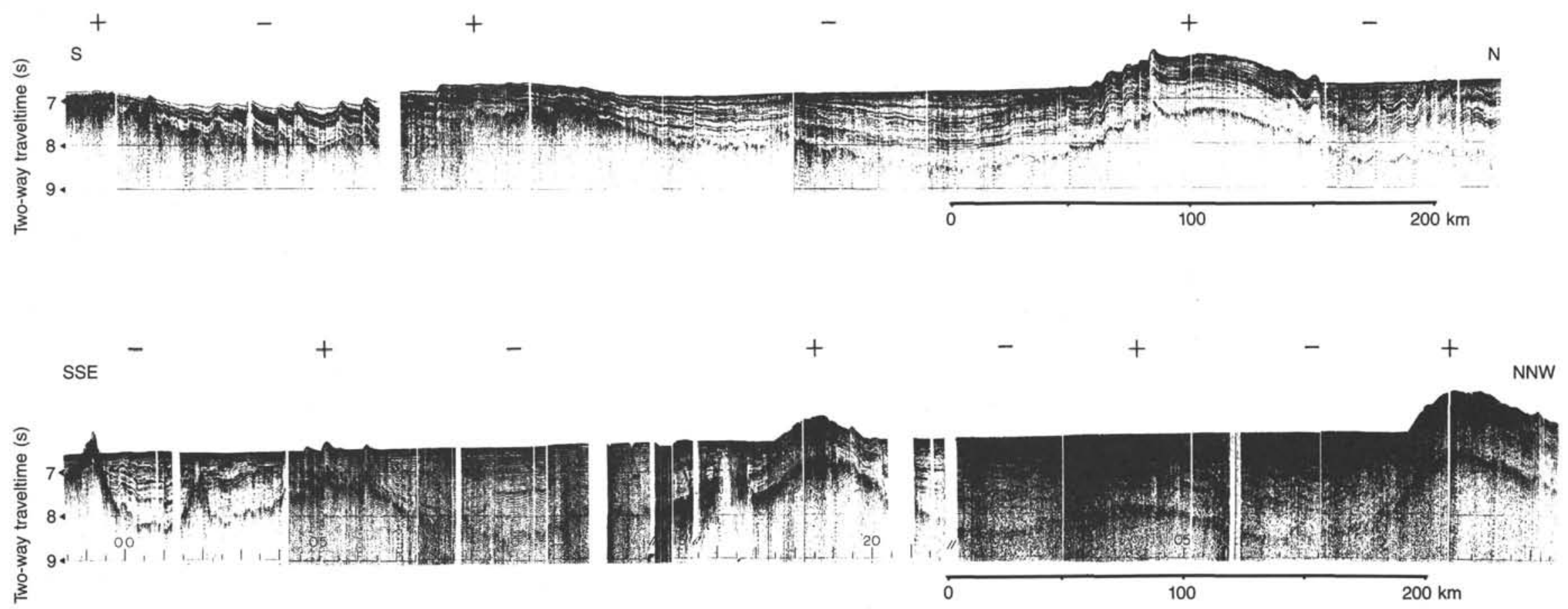

Figure 5. Single-channel seismic reflection profiles illustrating the undulatory nature of the long-wavelength basement deformation (after Geller et al., 1983). Location of these profiles is shown in Figure 6, site survey chapter. Symbols + and - denote highs and lows, respectively, of long-wavelength deformation. 


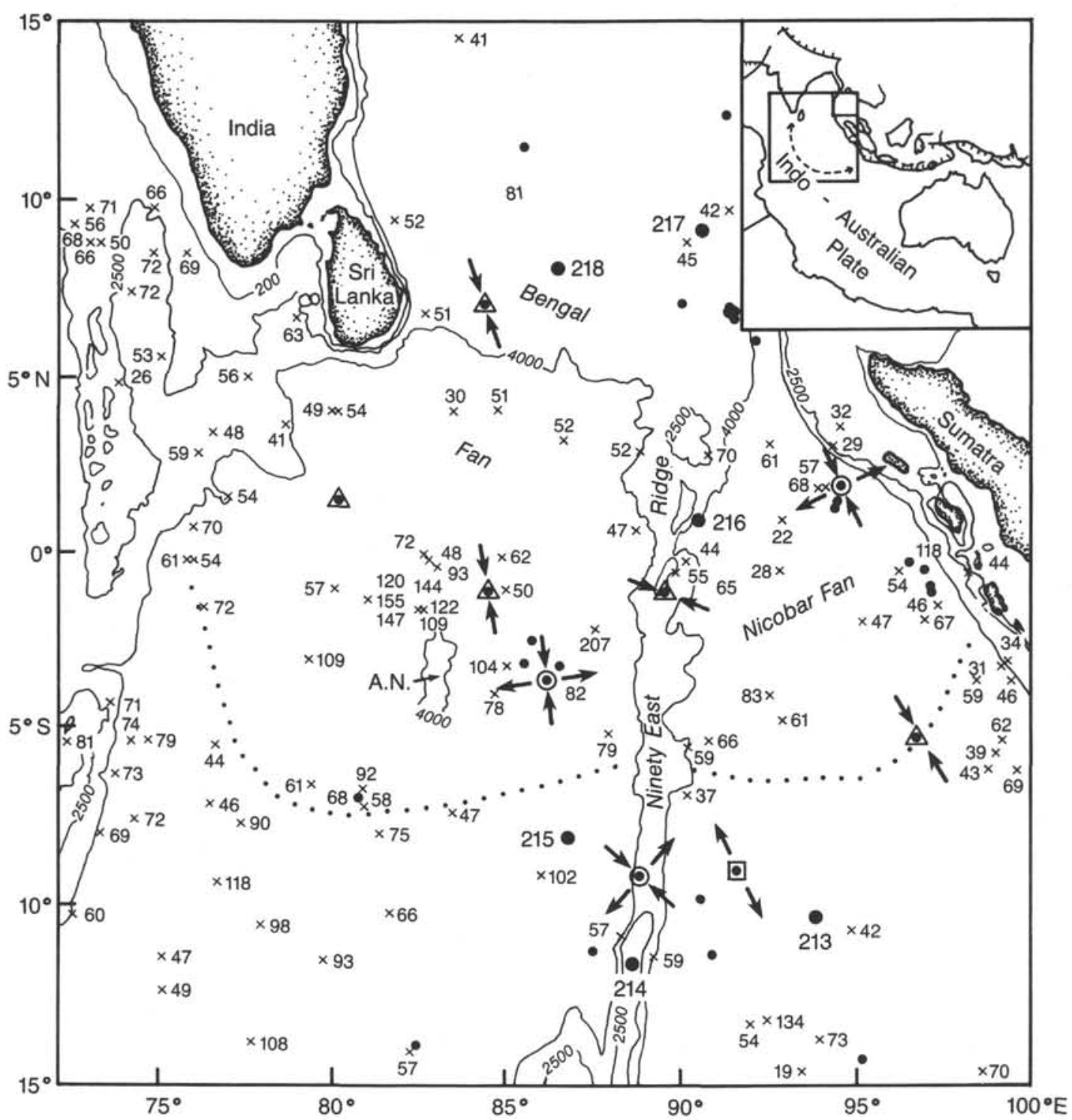

Figure 6. General geophysical setting of the lower Bengal Fan. X denotes the locations of heat-flow measurements (in $\mathrm{mW} / \mathrm{m}^{2}$ ) compiled by Geller et al. (1983). Large solid circles indicate DSDP site locations. A.N. is the Afanasy Nikitin seamount group. Solid dots are intraplate earthquakes. Triangles denote thrust focal mechanisms; circles, strike-slip mechanisms; and squares, normal mechanisms. The dotted line shows roughly the southern limit of fan deposits. The dashed line in the inset box (upper right corner) is the southern limit of the observed deformation. Strikes of principal stress axes for intraplate earthquakes within the Indo-Australian Plate are shown by arrows. Depths are contoured in meters (after Wiens et al., 1985).

The main questions we hoped to address during Leg 116 with regard to fan sedimentation were the following:

1. What have been the major controls on sedimentation and how have they interacted? Tectonic uplift and erosion of the $\mathrm{Hi}$ malayas has clearly been important, but we also expect to encounter the signature of local tectonics related to intraplate deformation. The latest rise in sea level at the end of the Pleistocene has clearly had a major affect on sedimentation, but it is not clear to what extent earlier sea-level changes were similarly important. Closely related are the Quaternary climatic changes in the Himalayas that may have had significant effect on the equatorial accumulation some $4000 \mathrm{~km}$ away.

2. What are the chief processes of sedimentation and what can we deduce about their characteristics? A range of different turbidites can be expected. Turbidite thickness, grain size, and structural sequence should indicate something of the size, competence, and evolution of the turbidity currents that deposited them, and of whether or not sediment by-passing has occurred in the middle fan area. The contribution from pelagic processes and the possible effects of bottom currents (Kolla et al., 1976) in the region of distal fan channel termination are not known. It is also possible that more local slumping and debris flow processes may have been periodically active.

3. Is the provenance of sediments on the distal Bengal Fan single or mixed? Clearly, a large proportion of the sediment must be derived from the Ganges-Brahmaputra drainage basin (Pimm, 1974; Ingersoll and Suczek, 1979). However, the distribution of clay minerals in the northeast Indian Ocean indicates the contribution from several different continental sources (Kolla, 1974). In addition, there may have been intrabasinal supply from adjacent seamounts or from areas of crustal deformation. 


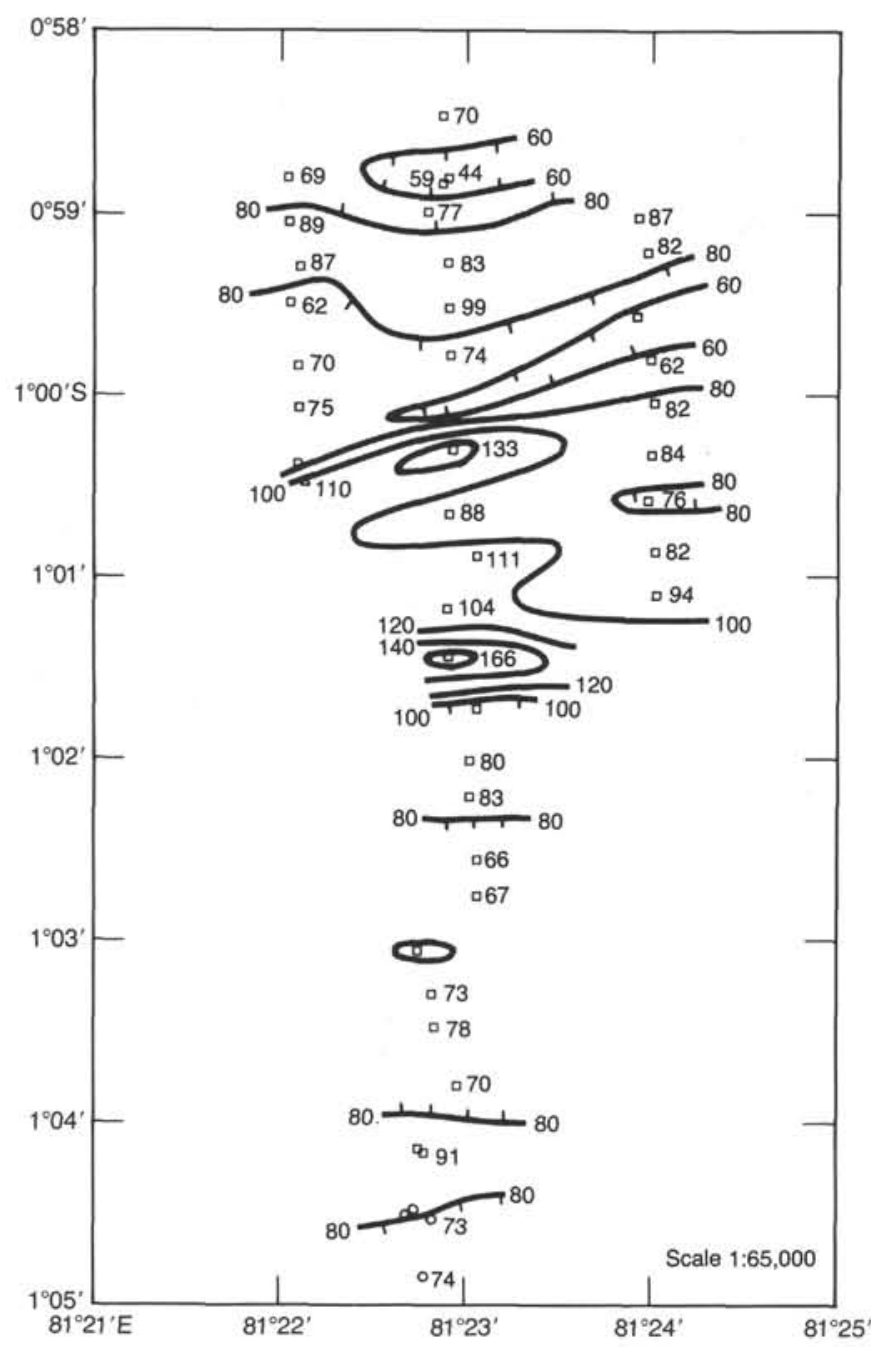

Figure 7. Detailed contour map of heat-flow anomalies. Squares and circles are heat-flow measurement stations with their values in $\mathrm{mW} / \mathrm{m}^{2}$ (after Weissel, unpublished data).

\section{EARLY DIAGENESIS}

Most work on diagenesis has focused either on the very early changes that take place in sediments related to their environment of deposition (i.e., 0 - to 10 -m burial depths), or on deep burial diagenesis and its effects on reservoir properties (in excess of $1000-\mathrm{m}$ burial). Fewer data exist on the diagenetic changes that occur between 10 and $1000 \mathrm{~m}$, although some work of this kind has begun to appear as a result of earlier DSDP/ODP legs (e.g., Stow and Miller, 1984).

The nature of these early diagenetic changes, which form the template for subsequent burial diagenesis, are in large part controlled by the unstable or metastable components within the sediments. These include amorphous $\mathrm{Al}, \mathrm{Si}$, and $\mathrm{Fe}$ oxides, biogenic $\mathrm{SiO}_{2}$ and $\mathrm{CaCO}_{3}$, organic carbon, and volcanogenic material. Other controlling factors include heat flow, pore-water chemistry and bottom-water oxygenation.

The sites to be drilled on the distal Bengal Fan were thought to provide an excellent opportunity to examine the influence of high heat flow on early diagenesis in stable deep oceanic sediments. Appropriate comparisons can then be made with, for example, work on diagenesis in the Mississippi Fan sediments (Thayer et al., 1986; M. R. Townsend, pers. comm., 1987).

\section{REFERENCES}

Anderson, R. N., Langseth, M. G., and Sclater, J. G., 1977. The mechanisms of heat transfer through the floor of the Indian Ocean. $J$. Geophys. Res., 82:3391-3410.

Bally, A. W., Allen, C. R., Geyer, R. E., Hamilton, W. R., Hopsen, C. A., Molnar, P. H., Oliver, J. E., Opdyke, N. D., Plafker, G., and Wu, F. T., 1980. Notes on the geology of Tibet and adjacent areas. Report of the American Plate Tectonics delegation to the Peoples Republic of China. U. S. Geol. Surv. Open-File Rep., 80-501.

Banghar, A. R., 1972. Focal mechanisms of Indian earthquakes. Bull. Seismol. Soc. Am., 62:603-649.

Bergman, E. A., Nabelek, L. J., and Solomon, S. C., 1984. An extensive region of off-ridge normal-faulting earthquakes in the southern Indian Ocean. J. Geophys. Res., 89:2425-2443.

Copeland, P., Harrison, T. M., Kidd, W.S.F., Xu, R., and Zwang, T., 1987. Rapid early Miocene acceleration of the uplift in the Gandese Belt, Xizang (southern Tibet) and its bearing on accommodation mechanisms of the India-Asia collision. Earth Planet. Sci. Lett., 86: 240-252.

Curray, J. R., and Moore, D. G., 1971. Growth of the Bengal deep-sea fan and denudation of the Himalayas. Geol. Soc. Am. Bull., 82: 563-572.

Curray, J. R., Emmel, F. J., Moore D. G., and Raitt, R. W., 1982. Structure, tectonics and geological history of the northeastern Indian Ocean. In Nairn, A. E. M., and Stehli, F. G. (Eds.), The Ocean Basins and Margins (Vol. 6), The Indian Ocean: New York (Plenum Press), 399-450.

Davies, T. A., and Kidd, R. B., 1977. Sedimentation in the Indian Ocean through time. In Heirtzler, J. R., Bolli, H. M., Davies, T. A., Saunders, J. B., and Sclater, J. G. (Eds.), Indian Ocean Geology and Biostratigraphy: Washington (Am. Geophys. Union), 61-86.

Eittreim, S. L., and Ewing, J., 1972. Midplate tectonics in the Indian Ocean. J. Geophys. Res., 77:6413-6421.

Emmel, F. J., and Curray, J. R., 1984. The Bengal submarine fan, northeastern Indian Ocean. Geo-Mar. Lett., 3:119-124.

Fitch, T. J., Worthington, M. H., and Everingham, I. V., 1973. Mechanisms of Australian earthquakes and contemporary stress in the Indian Ocean plate. Earth Planet. Sci. Lett., 18:345-356.

Gansser, A., 1964. Geology of the Himalayas: New York (Wiley Interscience).

1966. The Indian Ocean and the Himalayas, a geological interpretation. Eclogae Geol. Helv., 59:831-848.

Geller, C. A., Weissel, J. K., and Anderson, R. N., 1983. Heat transfer and intraplate deformation in the central Indian Ocean. J. Geophys. Res., 88:1018-1032.

Honegger, K., Dietrich, V., Frank, V. V., Gansser, A., Thoni, M., and Tremsdorff, V., 1982. Magmatism and metamorphism in the Ladakh Himalayas (the Indus-Tsangpo suture zone). Earth Planet Sci. Lett., 60:283-292.

Ingersoll, R. V., and Suczek, C. A., 1979. Petrology and provenance of Neogene sand from Nicobar and Bengal Fans, DSDP Sites 211 and 218. J. Sedimentol. Petrol., 49:1217-1228.

Kolla, V., 1974. Mineralogical data from Sites 211, 212, 213, 214 and 215 of the DSDP, Leg 22, and origin of noncarbonate sediments in the equatorial Indian Ocean. In von der Borch, C. C., Sclater, J. G., et al., Init. Repts. DSDP, 22: Washington (U.S. Govt. Printing Office), 489-502.

Kolla, V., Moore, D. G., and Curray, J. R., 1976. Recent bottom-current activity in the deep western Bay of Bengal. Mar. Geol., 21:255270.

McKenzie, D. P., and Sclater, J. G., 1971. The evolution of the Indian Ocean since the Late Cretaceous. Geophys. J. R. Astron. Soc., 25: 437-528.

Minster, J. B., and Jordan, T. H., 1978. Present-day plate motions. $J$. Geophys. Res., 83:5331-5334.

Moore, D. G., Curray, J. R., Raitt, R. W., and Emmel, F. J., 1974. Stratigraphic-seismic section correlations and implications to Bengal Fan history. In von der Borch, C. C., Sclater, J. G., et al., Init. Repts. DSDP, 22: Washington (U.S. Govt. Printing Office), 403412.

Patriat, P., and Achache, J., 1984. India-Eurasia collision chronology has implications for crustal shortening and driving mechanism of plates. Nature, 311:615-621. 
Peirce, J. W., 1978. The northward motion of India since the Late Cretaceous. Geophys. J. R. Astron. Soc., 52:277-311.

Pimm, A. C., 1974. Sedimentology and history of the northeastern Indian Ocean from Late Cretaceous to Recent. In von der Borch, C. C., Sclater, J. G., et al., 1974, Init. Repts. DSDP, 22:Washington (U.S. Govt. Printing Office), 717-804.

Powell, C.M.A., and Conaghan, P. J., 1973. Plate tectonics and the Himalayas. Earth Planet. Sci. Lett., 20:1-12.

Schlich, R., 1982. The Indian Ocean: Aseismic ridges, spreading centers and oceanic basins. In Nairn, A.E.M., and Stehli, F. G. (Eds.), The Ocean Basins and Margins (Vol. 6), The Indian Ocean: New York (Plenum Press), 51-148.

Sclater, J. G., and Fisher, R. L., 1974. The evolution of the east central Indian Ocean with emphasis on the tectonic setting of the Ninety East Ridge. Geol. Soc. Am. Bull., 85:683-702.

Sclater, J. G., Luyendyk, B. P., and Meinke, L., 1976. Magnetic lineations in the southern part of the Central Indian Basin. Geol. Soc. Am. Bull., 87:371-378.

Stein, S., and Okal, E. A., 1978. Seismicity and tectonics of the Ninety East Ridge area: Evidence for internal deformation of the Indian plate. J. Geophys. Res., 83:2233-2245.

Stow, D.A.V., 1985. Deep-sea clastics: where are we and where are we going? Geol. Soc. Spec. Publ. London, 18:67-93.

1986. Deep clastic seas. In Reading, H. G. (Ed.), Sedimentary Environments and Facies: London (Blackwell Sci. Publ.), 399446.

Stow, D.A.V., and Miller, J., 1984. Mineralogy, petrology and diagenesis of sediments at Site 530, southeast Angola Basin. In Hay, W. W.,
Sibuet, J-C., et al., 1984. Init. Repts. DSDP, 75: Washington (U.S. Govt. Printing Office), 857-874.

Sykes, L. R., 1970. Seismicity of the Indian Ocean and a possible nascent island arc between Ceylon and Australia. J. Geophys. Res., 75: 5041-5055.

Tapponnier, P., Mercier, J. L., Rengt, P., Adrieux, J., Armijo, R., 1981. The Tibetan side of the Indian-Eurasia collision. Nature, 294:405410.

Thayer, P. A., Roberts, H. H., Bouma, A. H., and Coleman, J. M., 1986. Sedimentology and petrology of Mississippi Fan depositional environments, Deep Sea Drilling Project Leg 96. In Bouma, A. H., Coleman, J. M., Meyer, A. W., et al., Init. Repts. DSDP, 96: Washington (U.S. Govt. Printing Office), 489-503.

von der Borch, C. C., Sclater, J. G., et al., 1974. Init. Repts. DSDP, 22: Washington, (U.S. Govt. Printing Office).

Weissel, J. K., Anderson, R. N., and Geller, C. A., 1980. Deformation of the Indo-Australian plate. Nature, 287:284-291.

Wiens, D. A., and Stein, S., 1983. Age dependence of oceanic intraplate seismicity and implications for lithospheric evolution. J. Geophys. Res., 88:6455-6468.

,1984. Intraplate seismicity and stresses in young oceanic lithosphere. J. Geophys. Res., 89:11441-11464.

Wiens, D. A., DeMets, C., Gordon, R. G., Stein, S., Argus, D., Engeln, F. J., Lundgren, P., Quible, D., Stein, C., Weinstein, S., and Woods, D. F., 1985. A diffuse plate boundary model for Indian Ocean tectonics. Geophys. Res. Lett, 12:429-432.

\section{Ms 116A-102}

